Ж. В. Колоїз

\title{
ПРАГМАТИЧНА ОРІЕНТАЦІЯ ОБРАЗНИХ ПОРІВНЯНЬ У МОВОТВОРЧОСТІ ЛІНИ КОСТЕНКО
}

Колоїз Ж. В. Прагматична орієнтація образних порівнянь у мовотворчості Ліни Костенко.

У статті досліджуються образні порівняння, засвідчені в поетичній творчості Ліни Костенко; аналізуються їхні семантичні, формально-граматичні та прагматичні особливості. Зроблено спробу систематизувати порівняння залежно від репрезентації спродукованих образів; з'ясовано особливості актуалізації відповідних знань, закодованих в образних порівняннях.

Ключові слова: образне порівняння, семантика, формальна структура, суб’єкт, ознака, образ, прагматична орієнтація.

Колоиз Ж. В. Прагматическая ориентация образных сравнений в творчестве Лины Костенко.

В статье исследуются образные сравнения, представленные в творчестве Лины Костенко; анализируются их семантические, формально-грамматические и прагматические особенности. Сделана попытка систематизировать сравнения в зависимости от репрезентации спродуцированных образов; рассматриваются особенности актуализхации соответсвующих знаний, закодированных в образных сравнениях.

Ключевые слова: образное сравнение, семантика, формальная структура, субъект, признак, образ, прагматическая ориентация.

Koloyiz Z. V. The pragmatic orientation of figurative comparisons in works of Lina Kostenko.

The article investigates the figurative comparisons, that are discovered in works of Lina Kostenko. Their semantic, formal-grammatical and pragmatic features are analyzed. An attempt to systematize the comparisons with according to representation of reflected types is made. The features of actualization of the proper information, which are coded in figurative comparisons, are studied. orientation.

Key words: figurative comparisons, semantics, formal structure, character, attribute, type, pragmatic

() Ж. В. Колоїз, 2011. 
Поетичне слово Ліни Костенко 3 його глибоким філософським підтекстом, що спонукає замислитися «над не сказаним безпосередньо, але легко вгадуваним», маніфестуючи життя окремої людини, «помножене на збагачену історичним досвідом пам'ять», репрезентує незалежне художнє мислення і високе мистецтво. Будучи предтечею шістдесятників, ламаючи звичні художні критерії, письменниця повертає українському поетичному слову естетичну повноцінність, підносить його на якісно новий інтелектуальний рівень, розбудовуючи національну культуру.

Ліна Костенко зі своїм філософським баченням сучасного їй світу осягає великі історичні простори, напружено шукаючи ключів до таємниць буття людини, нації, людства, відіграє значну роль в історії як українського письменства, так і української літературної мови. А відтак іiї творчий доробок привертає увагу не лише літературознавців, а й лінгвістів. I насамперед тому, що будь-який художній текст розглядається як можливість виявити мовні особливості стилю й індивідуальної словеснотворчої манери письменника в іï проекції на загальнонародну мову. До того ж на сучасному етапі розвитку лінгвістики мову, зокрема й художню, закономірно розглядають як таку, що допомагає зрозуміти культуру етносу, його світоглядну систему, ціннісні орієнтири.

Особливості функціонування поетичного слова вже неодноразово ставали предметом спеціальних наукових розвідок як у вітчизняному, так i зарубіжному мовознавстві (Н. Арутюнова, А. Вежбицька, П. Грищенко, С. Срмоленко, В. Калашник, Л. Лисиченко, Л. Мацько, А. Мойсеєнко, Л. Пустовіт, Л. Савченко, Н. Сологуб, Л. Савицька, Г. Сюта, В. Телія та ін.) Вони переконливо демонструють те, що поетичне слово має вагомий вплив на формування національної культури, сприяє збагаченню мовної системи, зокрема й зображально-виражальними засобами.

Мовотворчість Ліни Костенко, апелюючи не лише до розуму, але й до почуттів, маніфестує потужний зображально-виражальний потенціал. Нестандартне художнє мислення спонукає письменницю до нестандартного оформлення повідомлюваного матеріалу. Її зусилля спрямовані на пошук таких комунікативних параметрів, які забезпечили б не абстрактний обмін інформацією, а той реальний процес спілкування, що складається 3 багатьох компонентів, до яких належать й інформативний зміст, і вплив на читача, і контролювання його вчинків та почуттів.

У письменницькому поетичному доробку доволі часто ставлення до дійсності виражається не прямо, а опосередковано, через подібність до чогось іншого, загальнішого, типовішого, через порівняння. Слід зауважити, що останнє як стилістична фігура, «що полягає в зображенні особи, предмета, явища чи дії через найхарактерніші ознаки, які $\epsilon$ органічно властивими для інших» [7, с. 469], викликає неабияке зацікавлення в мовознавців (С. Александрова, Л. Голоюх, А. Довженко, А. Найда, Т. Павлюк, О. Федорів та ін.). Дослідження його особливостей 
здійснюється як безпосередньо (на відповідному фактичному матеріалі), так і опосередковано, крізь призму різних взаємовідношень (І. Гапєєва).

У пропонованій статті маємо на меті здійснити формальносемантичний аналіз образних порівнянь, що репрезентують авторське уявлення про дійсність, та продемонструвати їхню прагматичну орієнтацію.

В основі порівняння, як відомо, лежать логічні операції виокремлення найсуттєвішої ознаки описуваного через пошук іншого, для якого ця ознака є виразнішою [7, с. 469]. Формальна структура цієї стилістичної фігури передбачає здебільшого три обов'язкові компоненти: 1) основу (те, що порівнюється); 2) ознаку (те, на основі чого порівнюється); 3) образ (те, 3 чим порівнюється). Відповідно до наявності / відсутності необхідних складових компонентів і семантичних відношень між основою та образом прийнято диференціювати порівняння як логічні та образні. Суть перших полягає в тому, що зіставляються однорідні явища чи предмети: Що, розуме, скептичний мій химернику? Не прикидайся, ти сумуєи теж. Любов відкрити важче, ніжк Америку. По-перше, чи до неї допливеш? [4, с. 280]; ...nисали якісь картини - картини, дешевші від рам [4, с. 370]; Він був, як ми, блакитний від ожини. I через те ми дуже з ним дружили [4, с. 393]; Ввійшла в кабінет, як ніхто ще не входив, така квітуча, струнка на подив, така весела, така чорноброва! [4, с. 402] тощо. У таких ситуаціях встановлюється ступінь схожості чи відмінності між предметами одного класу, беруться до уваги всі властивості, якості, ознаки порівнюваних предметів, проте акцентується на чомусь одному (пор.: відкрити любов (важко) - відкрити Америку; картина - (дешева) - рама і т. ін.).

Образні порівняння грунтуються на тій чи тій найвиразнішій ознаці, яка $\epsilon$ найбільш прийнятною для зіставлення в конкретній ситуації спілкування. Причому ця ознака кваліфікується передусім як процесуальна чи непроцесуальна: I засміялась провесінь: - Пора! - за Чорним Шляхом, за Великим Лугом - дивлюсь: мій прадід, і пра-пра, пра-пра - усі ідуть за часом, як за плугом. За ланом лан, за ланом лан і лан, за Чорним Шляхом, за Великим Лугом, вони уже в тумані - як туман - усі вже йдуть за часом, як за плугом [4, с. 4]; Кулі примхливі, як дівчата, - вибирають найкраших. Підлість послідовна, як геометрія, - вибирає найчесніших. В 'язниці гостинні, як могили, - вибирають неприборканих [4, с. 36]; I тільки на привалі, в ті рідкісні хвилини, коли ще в свої тачки жінки не запряглись, ті буковки вірменські виводять, як стеблини, $і$ слізьми поливають, і букви прийнялись [4, с. 23]; Того не можна. I того не слід. Пласка як дошка. Голос - наче блямба. Маслакувато затуливши світ, танцює ритуальні танці штампа [4, с. 166]; I ияя печаль, прискіплива, як слідчий. I ия строфа, оголена, як відчай.I дикий хміль, примерзлий до воріт. I на криниці необбитий лід [4, с. 212] тощо. Маніфестовані образи дають змогу побачити щось нове, раніше приховане, у характеристиці відповідних реалій об’єктивного світу. До того ж значна кількість 
образних порівнянь належить до розряду традиційних, які переважно усталилися в загальнонародній мові: Як мені легко, щзоб їм так дихати! Рано я, рано зосталась вдовою, та й попливла, як лист за водою. Живу одна, живу, як черниця [4, с. 121]; Впиралась чолом у погашені гасла, крізь товшу стелі росла в надію $і$, як свіча, без повітря гасла [4, с. 142]; Він тихо іде, він повільно іде. У нього й чоло ще таке молоде! Хто скаже про нього: старий він як світ? Він - Данте. Йому тільки тисяча літ [4, с. 224]; Сходить місяџзь, як дінжа [4, с. 373]; Вони не те щзоб просто так мовчали, - вони себе з живущуих виключали, вони робились білі, як стіна [4, с. 387]; I знову мчиш, як метеор, ти. I довго світяться в душі оті розкішні натюрморти уздовж доріг на спориші [4, с. 123]; Пройшли усе Поділля. Намети і монети. Добралися до Польщі. Циганки - ну $i$ ну! Ото десь по містечку як пройдуть, мов комети, - там щзезне кріль, там курка, там глечик на тину [4, с. 402] тощо. Їх постійне використання в різних текстах художнього мовлення певною мірою знижує прагматичний потенціал, попри те, що вони продовжують залишатися емотивно значущими та стилістично привабливими, оскільки не лише називають, але й виконують оцінну функцію. Порівняння, ужиті при дієсловах, зокрема дієсловах руху, забезпечують динамічність, підсилюють стрімкий, напружений характер його протікання (пор.: пливти, як лист за водою; мчати, як метеор; пройти, як комета і т. ін.). Швидкоплинність виявляється в зіставленні предметів живої та неживої природи.

Образні порівняння Ліни Костенко розмаїті i за семантикою, i за формальною структурою. Цілком закономірно, що найпродуктивніше представлені так звані сполучникові порівняння, уведені у структуру комунікативної ситуації за допомогою порівняльних сполучників. Вони являють собою як непоширені (Не треба думати мізерно. Безсмертя є щзе де-не-де. Хтось перевіяний, як зерно, у трунт поезї впаде [4, с. 38]; Той клавесин і плакав, і плекав чужу печаль. Свічки горіли кволо. Старий співак співав, як пелікан, проціджуючи музику крізь воло. На голови, де, наче солов'ї, своє гніздо щуоня звивають будні, упав романс, як він любив ї̈ $i$ говорив слова їй незабутні. Він цеей вокал підносив, як бокал. У нього був метелик на маніжиі. Якісь красуні, всупереч вікам, до нього йили по місячній доріжиі [4, с. 46]; Ще вчора була я висока, як вежа. Здається, ще трохи - дістану зеніт. I раптом, як вибух, - обвал $i$ пожежа. Розтрощуений камінь - уже не граніт. [4, с. 58]), так і поширені порівняльні звороти (Я пурхала в саду, розгойдувала квітку. Полохала в гнізді пташину боязку. А вранцуі крізь бузок дивилася на тітку, котра була чомусь - як свіюний кущ бузку [4, с. 68]; Зненацька м'язи вибухнуть, первісно, ударить кров, як електричний струм [4, с. 74]; Морями пшениці, у пахощуах м'яти, де літо стоїть, як мальований глек, пливуть $i$ пливуть колискові фрегати, летять космонавти на крилах Лелек [4, с. 111]; А ліс, як дрейфуюча шхуна, скрипів, у льоди закутий [4, с. 126]), 
рідше - залежні предикативні частини, поєднані 3 головною на основі порівняльних семантико-синтаксичних відношень(Тебе, незнаного, впізнаю, як син вигнанця впізнає прикмети батьківського краю. Нехай це - витвір самоти, нехай цฺе - вигадка й омана! Моєму серцฺю снишся ти, як морю сняться урагани [4, с. 125]). I порівняльний зворот, і порівняльна предикативна частина можуть мати при собі іншу предикативну частину, яка увиразнює попередню «стилістичну інформацію» (I cumi масні ретрогради, такі між собою приязні, як ті торгаші біблійні, щцо разом пропхалися в храм, тримали твоє мистецтво, як горизонт на прив'язі, писали якісь картини - картини, дешевші від рам [4, с. 370]), подекуди ілюструє зразок синтаксичного паралелізму (Я в людей не проситиму сили, я нічого в житті не просила, як не просять гранітні схили, щцоб у спеку домі їх зросили [4, с. 130]).

Граматична форма орудного порівняння - явище нетипове для творчого доробку Ліни Костенко: Стоять мости над мертвими річками. Лелека зробить декілька кругів. Очерети із чорними свічками ідуть уздовж колишніх берегів [4, с. 53]; У нього й хмари вигинались зміями [4, с. 96]; Коли ридали сосни янтарем $і$ динозаври ніжились в щзириці, коли щуе жив у пралісі пралев, коли у небі глибали праптищу, коли льоди зсувалися із гір і ще була не ящірка, а ящір, - який він був, мій особистий пращур, неандерталецьь, вертикальний звір? [4, с. 348]. Значно активніше вдається письменниця до використання описових порівняльних конструкцій з компонентом схожий: Там жив дідок, щзо схожий був на графа, в краватцуі чорній, не як всі діди [4, с. 19]; Голубими дощзами сто раз над тобою заплачу, Гіацинтовим сонцем сто раз над тобою зійду. Ми 3 тобою такі безборонні одне перед одним. Ця любов була схожа на таӥнство периих причасть [4, с. 314]; Строката хустка - жовте $i$ багряне - $з$ плечей лісів упала їм під ноги. I вся природа схожна на циганку - вродливу, темнооку, напівголу, в червоному намисті з горобини, з горіховими бубнами в руках [4, с. 343]; Ще не було ні анта, ні венеда. Але під вечір, на розливі рік, старий валун був схожий на ведмедя - $i$ зупинився дикий чоловік. Над ними пролітає птеродактиль, прогуркотівии, наче вертоліт [4, с. 351]. Прагматично орієнтованими є й так звані заперечні порівняння: Згоріли їхні храми. Мужчини їхні вбиті. Втонули їхні дзвони у озері Севан. О, як їм далі жити? На тім кровопролитті не місяць в небі сходить - турецький ятаган [4, с. 23]; Що ж, авторучка - це не шабля з піхов. Ворожа кров не бризне з-під пера. I лиє дощу. I гетьман не приїхав. Неслушний час. I все-таки пора. Пора, пора! Живеться, як на Етні. Ганьбу віків лиш магма відпере. Це лии слова. Зате вони безсмертні. Вгамуйте лють. Їх куля не бере [4, с. 165]; A ноги довгі, ноги, не котурни. Б'ють по литках терни і бур'яни. Стугнить земля. Ідуть великі юрми. Ти думав - люди, глянув - барани [4, с. 176]; Ox, я не Фауст. Я тільки жінка. Я не скажу: "Хвилино, спинись!» Хвилино, 
будь! [4, с. 311]; Петро - не Юда. Він любив Учителя. І вуст він зроду був би не отверз. ...Коли вели Ісуса до мучителя, була сльота. Петро апостол змерз [4, с. 367]. Порівняння, побудовані на принципі заперечення, допомагають виділити певну ознаку в суб'єкта та об'єкта. Прийом заперечення нібито руйнує цю тісну спорідненість і тим загострює враження, а частка не створює роздільну порівняльну ситуацію. Наприклад, авторучка для поета - це зброя, щоправда, не така ефективна, як шабля; довгі ноги - це частина людського організму, здатна відчувати біль, на відміну від котурнів - взуття з дуже високою підошвою.

Особливим зображально-виражальним потенціалом вирізняються порівняння, репрезентовані прикладкою - непоширеною / поширеною, невідокремленою / відокремленою: Син білявого дня $i$ чорнявої ночі, вечірмулат підійшов до порога. Слухай, мулате, бачиш ті ночви, - нехай иее буде стара пірога [4, с. 181]; Руки шовковищь, чого ж ви заклякли? Вікна забиті, і висить замок - ржсава сережка над кігтиком клямки [4, с. 15]; Отакі вони хлопці, кирпаті сільські аргонавти, голуб'ята, анцицболи, хоч не роди! Під горою стояла вагітна, як поле, мати. I кричала та мати: Хоч личко його покажіть! [4, с. 32]; Півкроку вбік - i все цуе піде прахом. I цілий всесвіт вміститься в сльозу. Дрімотні міни - круглі черепахи - в землі шорсткій ворушаться, повзуть [4, с. 75]; Поету важко. Він шукає істин. Ми - джсини в закоркованих пляшках. $A$ ви, хто ви, які же ви комуністи? Ви ж комунізм вдавили в пелюшках [4, с. 169]; Хай буде легко. Дотиком пера. Хай буде вічно. Спомином пресвітлим, Цей білий світ березова кора, по чорних днях побілена десь звідтам [4, с. 279].

Іноді зіставлення тих чи тих явищ дійсності відбувається приховано, унаслідок чого порівняння модифікується в метафору: A вікна сплять, засклив мороз їм сльози, У вирій полетіли рогачі [4, с. 41]; Пасуться тіні вимерлих тарпанів, навшпиньки ходять сутінки $і$ сни. Весна підніме келихи тюльпанів, - за небо вип'ю $і$ за дві сосни! [4, с. 44]; Чому ліси чекають мене знову, на щит піднявши сонще $i$ зорю. Я їх люблю. Я знаю їхню мову. Я з ними теж мовчанням говорю [4, с. 50]; Правічну думу думають ліси, вгрузають в мох столітні дідугани [4, с. 328]. Такі метафоричні порівняння співіснують із власне порівняльними зворотами чи то в межах конкретної ситуації, чи то в межах надфразної єдності: I дощ, $i$ сніг, і віхола, і вітер. Високовольтна лінія Голгоф. На біле поле гайвороння літер впаде як хмари, изілі хмари строф. Нове століття вже на видноколі, i час новітню створює красу. А ритми мчать- як вериники у полі. А рима віршам запліта косу [4, с. 21]; На конвертики хат літо клеїть віконця, як марки. Непогашені марки - біда щуе не ставила штамn [4, с. 43].

Діапазон авторських образних порівнянь у поетичному доробку письменниці досить широкий. Поетизуються насамперед конкретні предмети. I це цілком закономірно, адже людина як суб'єкт відповідної ситуації спілкування сприймає і відображає дійсність через світ речей 
живої природи. Людина є вищим ступенем живих природних організмів, суб'єктом суспільно-історичної діяльності та культури, який створює матеріальні умови свого існування. Природа створила людину, людина перетворює природу. Їх співіснування і взаємодія $\epsilon$ основною умовою людського життя. Останнє доволі часто виступає в ролі суб'єкта порівняння: Життя - страшна корида,На сотню Мінотаврів - один тореадор [4, с. 114] (пор.: життя - корида, де корида - «бій», ісп. corrida (de toros), букв. біг (биків) - в Іспанії та деяких країнах Латинської Америки бій тореадора 3 розлюченим биком [6, с. 560]); Життя, мабуть, - це завжди Колізей. I завжди люди гинули за віру. Цей спорт одвічний винайшли не ми. Тут головне - дивитись в очі звіру і просто залишатися людьми [4, с. 206] (пор.: життя - Колізей, де Колізей - «арена для боїв», італ. Coliseo < лат. Colosseum < colosseum - велетенський амфітеатр Флавіїв у Римі, призначений для боїв гладіаторів та інших видовищ [6, с. 535]); Життя - це божсевільне ралі [4, с. 263] (пор.: життя - paлi, де ралі - «змагання», англ. rally, букв. збори, зліт спортивні змагання на спеціальних автомобілях або мотоциклах [6, с. 682]); Життя - як вокзал. Хтось приїжджав, хтось від’ їжджав. Почілунки і рани, клунки і чемодани, слова і фрази - все разом [4, с. 148] (пор.: жстття - вокзал, де вокзал - «рух», англ. Vauxhall - назва парку i закладу для розваг поблизу Лондона - приміщення для обслуговування пасажирів, управління рухом транспорту і т. ін. [6, с.223]). В основі порівняння життя лежать найрізноманітніші ознаки, що сприяє появі найнеочікуваніших, доволі часто розгорнутих, образів: Настане час - і піде все в архів. Уламки долі винесе на сушу. Життя - спокута не свойх гріхів. Життя - ие оббирання з реп'яхів, що пазурами уп'ялися в душу [4, с. 178]; Життя - ие справа без гарантії. Чаклунок ми караєм по закону. Перехрестіться, пане, на ікону. Скажіть суду: вона із димаря [4, с. 382]. Життя - це рух. Тому його порівняння відбувається й на основі процесуальної ознаки: Мені відкрилась істина печальна: Життя зникає, як ріка Почайна [4, с. 77] (пор.: життя зникає - зникає ріка Почайна). 3 названою рікою пов'язані значущі події в історії Київської Русі: багато істориків стверджують, що хрещення киян у 988 році відбулося саме в цій річці, яка протікала північною околицею Подолу й впадала у видовжену затоку Дніпра (пор.: Почайна і початок (епохи християнства), очевидно, мають спільний корінь). На сьогодні ріка Почайна вже зникла з лиця землі. А відтак історична довідка дає змогу конкретизувати семантику - зникає безслідно.

Тривалість життя вимірювана. Воно змінюється в часі й просторі, зачіпаючи основного свого суб'єкта - людину. Тому не дивно, що всі ці поняття піддаються поетизації: людина - грудочка тепла у Всесвіті; Всесвіт - акваріум планет (Страждаю, мучусь, $i$ живу, $i$ гину, благословляю біль твойх тенет. Цю грудочку тепла - у Всесвіті людину! I Всесвіт ией - акваріум планет [4, с. 33]); душа - держава 
(Душа - сдина на землі держсава, де с свобода чиста як озон [4, с. 261]); час - секундант (Замліє степ козацькими могилами. Минає час, єдиний секундант. Стоїть вітряк з опущеними крилами. Стриножений пасеться Росінант [4, с. 180]); день - нотна сторінка вічності (Чорна ніч інкрустована ніжністю. Горизонт піднімав багряним плечем день - як нотну сторінку вічності. Слово - прізвище думки тепер, а частіше - ї̈ псевдонім [4, с. 8]; мить - чек (На старих фотографіях всі молоді. За роками людина сама себе кличе. У зіницях печалі, як в чорній воді, відбиваються люди, дерева, обличчя. I стонадияятий сніг ті поля притрусив, $і$ уже прилетять не ті самі лелеки. Біля каси такий незворушний касир, зафіксовану мить вибиває, мов чеки [4, с. 392]); земля - панции черепах (Земля - як панцир черепах, лежить, не змита $i$ грозою. Вишневий Хутір у степах немов пропечений сльозою [4, с. 190]) тощо. Причому відбувається зближення слова-основи зі словом або словами-образами, які є семантично далекими в нормативній мові (пор. також: Синіс день, як пізні капусти. Приходив дощ, а потім було зимно. Біднесенький мій ліс! - він крила опустив. Нема грибів, хоч би який мізинок $[4$, с. 345]).

Невід’ємною складовою життя самої поетеси є іiі професійна діяльність й усе, що пов'язано 3 нею. Осмислення призначення поета й поезії відбувається крізь призму опоетизування думки, голосу, слова, ритму, вірша, поезії, поета і т. ін.: Слова як сонце сходили в мені. Несказане лишилось несказанним [4, с. 14]; Я скучила за дивним зойком слова. Мого народу гілочка тернова. Гарячий лоб до иибки притулю [4, с. 17]; Але поет природний, як природа. Од фальші в нього слово заболить[4, с. 69]; Яка різниця - хто куди пішов? Хто щуо сказав, $i$ рима вже готова. Поезія - це свято, як любов. О, то не є розмовка побутова [4, с. 93]; Слова росли із грунту, мов жнита. Добірним зерном колосилась мова. Вона як хліб. Вона мені свята. I кров'ю предків тяжко пурпурова [4, с. 161]; Відходять вірші, наче поӥзди. Гримлять на рейках бутафорські строфи. Але куди? Куди вони, куди?! Поезія на грані катастрофи [4, с. 173]; А геніальні поети - такі бездарні. Виходять 3 ночей аж чорні, як шахтарі з забою. A ті клаптенята паперу - то смертельні плацдарми самотньої битви з державами, а часом, з самим собою [4, с. 175]; Мої думки печальні, наче клоуни, щуо, сміючись, розмазують сльозу [4, с. 176]; Поети - ие біографи народу, а в нього біографія тяжка [4, с. 270]; Душа шукає слів, як молитов. До синіх вікон туляться дерева [4, с. 284]; Мої думки, як дикі голуби, в полях шукали синього притулку [4, с. 293] тощо.

Авторські порівняння дають змогу простежити динаміку образів. Так, скажімо, образ струни виникає на основі зіставлення з нею, з одного боку, голосу (А очі у неї - такі тривожні, $і$ голос бринить - як струна [4, с. 120]), з іншого, - нервів (А нерви ж мої, ох нерви, струни мої, 
наструнчені на епохальний лад. А мені ж, може, просто хочеться щуастя, тугого й солодкого, як шоколад [4, с. 209]). В іншому разі нерви порівнюються з дротами (І тільки злість бував геніальна. Господь, спаси мене від доброти! Така тепер на світі коновальня, щзо треба мати нерви, як дроти [4, с. 209]), які, у свою чергу, зіставляються з арфою, як-от у контексті Колись давно, в сумних біженських мандрах, коли дитям я ледве вже брела, старі хатки в солом'яних скафандрах стояли в чорних кратерах села. Дроти бриніли арфою Ерделі [4, с. 73] (пор.: Ксенія Ерделі - арфістка, що створила школу гри на арфі). Один і той же суб'єкт порівняння, залежно від тієї чи тієї виокремлюваної ознаки, зумовлює появу різних образів: Проходять люди гарні $i$ незлі. В пахучій хмарі дощуової глиці стоїть туман, як небо на землі [4, с. 44] (пор.: туман (основа) - стоїть (ознака) - як небо на землі (образ ); Люблю хати древлянського Полісся, ті старовинні рублені хати - кремезні, довгі, сірі од сльоти, де кущ туману, як бузок, розрісся [4, с. 412] (пор.: туман (основа) - розрісся (ознака) - як кущ бузку (образ). Іноді ознака $\epsilon$ імпліцитною, автор дає змогу читачеві самостійно «домальовувати» образні характеристики: На оболонях верби у болоньях, туман, туман нейлонові плащі [4, с. 341]; Циганська дітвора, сунделики кучматі, тягають той папір цичанам на розкур. Ми плем'я. Ми горох. Ми котимось по світу. Там пригорщза. Там жменя. А кореня - ніде...Знялися і пішли. У нас нема адреси. I извинтарів нема. Ми вітер. Ми туман [4, с. 403-404] (пор.: у першому контексті актуалізується сема огортати (вдягати), у другому - розсіюватися). У контекстах Вечір-мисливець підстрелене соние несе у сірому ягдташі. Тягнуться хмари - скривавлені крила - по травах, по обрію, по душі... [4, с. 119] та Убога торба - хмара на плечі [4, с. 334] порівняння хмари з крилами і торбою відбувається за ознакою «зовнішній вигляд». Причому актуалізується і сема розмір, і сема колір.

Деякі зі спродукованих унаслідок порівняння образів мають інтегральні характеризуючі ознаки, які, щоправда, у межах конкретних ситуацій можуть залишатися «незадіяними»: Струшується сад, як парасолька. Мокрі ниви, і порожній шлях.. Ген корів розсипана квасолька доганяє хмари у полях [4, с. 92]; Пливе над світом осінь, як медуза, і мокре листя: падає на брук [4, с. 78] (пор.: сад (основа) - струшує (ознака) - як парасолька (образ) та осінь (основа) - пливе (ознака) - як медуза (образ), де медуза - статева форма кишковопорожнинних тварин; вільноплаваючий організм, який зовні нагадує парасольку). У другому разі зіставлення відбувається не на основі зовнішнього вигляду, а виконуваної функції.

Варто зауважити, що відображення дійсності в поетичному доробку Ліни Костенко маніфестується здебільшого в образах живої природи, більшою мірою тваринного i меншою - рослинного світів: Смуток нащуадків - як танець бджсли, танец̧ь бджоли до безсмертного поля [4, с. 15]; Десь блискавки - як бліции репортера, проекиія на хмару грозову. 
На плечі стрибне слава, як пантера, - він не помітив, бо косив траву. Я ж не самотній тут, як вовк. У мене гарне товариство - Шекспір, $i$ Лермонтов, і Блок [4, с. 244]; Вдень щуе літо, а надвечір - осінь. В склепі ночі похорон тепла. Вийдуть в ранок яблуні, як лосі, розсохаті роги дибала. Пийте воду, поки ще ласкава. Лосі, лосі, жумрайте траву. Так думки печаль прополоскали,щуо, як сад під зливою, живу [4, с. 329]; Болить життя. А справи дуже древні. Раби - як риби, замерзає кров [4, с. 381]; Лишай косу в сусіда на тину. Іәи у кадр, екран - твоя домівка [4, с. 37]; Блажен той муж, воістину блажен, котрий не був ні блазнем, ні вужем. Котрий вовік ні в празники, ні в будні не піде на збіговиська облудні. І між людей не буде одиноким, стоятиме, як древо над потоком [4, с. 216]; Сухі гілки - це вже вінок терновий. Останній клен світ за очі забіг. Залишиться єдиний лист кленовий - бетонний лист - розв'язкою доріг [4, с. 76]; Він був святий. Він жив непогрішимо. I не за гроші будував свій храм. Різьбив вівтар, збивав тесові паперті, клав палецьь свічки тиші на вуста, де з малювань, тонких, як листя папороті, світився лик розп'ятого Христа [4, с. 386]; $C$ вірші - квіти. Віриі - дуби. С іграшки вірші, $C$ повелителі $i$ раби [4, с. 143]; Гривастий грім, лоша моє невкоськане! - цвістиме в зорях ніч, як бульденеж [4, с. 195] (пор.: бульденеж < франц. boule de neige, букв. - снігова куля - садова декоративна форма калини, великі квітки якої утворюють кулеподібні суцвіття, схожі на снігові кулі [6, с. 191]) тощо. Впадає в око те, що фаунонімічні та флористичні образи здебільшого представлені лексемати, які ілюструють ненаціональний менталітет: Опускаюсь на землю, на сизий глобус капусти. На самісінький полюс, де ходе жук, як пінгвін [4, с. 43]; $A$ той старий, достоту Каліостро, щуось прецчизійне маючи в руціі, дивився в шкельце, наче кібець, гостро, $і$ поціляв у гвинтики й зубизі. ...У мерехтінні маятників мідних, округлені, як очі камбали, дзитарики замовників безслідних на підвіконні цзокали, ішли [4, с. 19] (пор.: кібецьь - хижий птах родини соколових, переважно з сірим або рудим пір'ям [3, с. 427]); Суха, порепана дорога повзе, як спраглий крокодил [4, с. 45]; Було в ній каміння - як сто бегемотячих спин [4, с. 56]; Ми прилетіли вранці у Європу. Блискучий лайнер випустив шасі. I кинув міст сталеву антилопу в ласо доріг, тунелів $і$ таксі [4, с. 102]; Поезія згубила камертон. Перецвілась, бузкова $i$ казкова. I дивиться, як скручений пітон, скрипковий ключ в лякливі очі слова [4, с. 173]; Вже пси вишкіряють на мене, як леви, криваві пащуі [4, с. 217]; I тільки сонцуе, сонцуе, сон... над нерозгаданістю літер на скелі дикій, як бізон [4, с. 242]; В гірких оазах сонячної цеедри, де грім тримав зливу в рукаві, де тільки версти, дерев'яні зебри, пасуться в запорошеній траві [4, с. 287]; Маленький хлопчик пас верблюда. То був життя його прелюд. Верблюд довірливий, як люди, I терпеливий - як верблюд [4, с. 94]; Сонце радісно пряжить, сонце - як ананас [4, с. 159]; Я воду пив з долоні, як із лотоса [4, с. 191]; Вбитий на 
снігу, я спам'ятався в зоряній пустелі. I все, щзо має на землі вагу, осипалось, як мертві імортелі [4, с. 236] (пор.: імортелі - франц. Immortel - безсмертний - рослини кількох родів родини складноцвітних; безсмертники [6, с. 460]) тощо.

У поетичній картині Ліни Костенко органічно поєдналися здобутки як вітчизняної, так і світової культури: міфології, релігії, історії, літератури i т. ін. Реалії об’єктивного світу зіставляються передусім з міфологічними та фольклорними персонажами, що репрезентують національну ментальність: Шукайте цензора в собі. Він там живе, дрімучий, без гоління. Він там сидить, як чортик у трубі, $i$ тихо вилучав вам сумління [4, с. 12]; Немов чарівні декорації - жасмин, троянди $і$ бузок. Кузини мамині, три грації, як три принцеси із казок [4, с. 29]; Цей ліс живий. У нього добрі очі. Шумлять вітри у нього в голові. Старезні пні, коилаті поторочі, літопис тиші пишуть у траві. Дубовий Нестор дивиться крізь пальці на білі вальси радісних беріз. I сонний гриб в смарагдовій куфайщі дощу напився $і$ за день підріс [4, с. 51]; В старім гнізді танцюють лелечатка, $i$, одірвавши ніжки від землі, немов малі русалоньки, дівчатка гойдаються в зеленому гіллі [4, с. 112]; I гірко в нічній глушині запалять люльки серед моху старі бородаті пні - підданці царя Гороха [4, с. 124]; 3 усіх трибун - аж дим над демагогом. Усі беруть в основу ленінізм. Адже ніхто так не клянеться богом, як сам диявол той же шовінізм [4, с. 163]; Вони все розуміли, вибачали, але мовчали, тяжко так мовчали, неначе в них вселився сатана [4, с. 387]; Гуде вогонь - веселий сатана, червоним реготом вихоплюється з печі, $A$ я чолом припала до вікна, і смуток мій бере мене за плечі [4, с. 293]; Закинь своє перо. Як чорта, бійся преси. Ще прийдуть нас вивчать, та й буде нам капкан [4, с. 404].

Засобом вираження етносвідомості, національного характеру, духовної культури слугують також образні порівняння, спродуковані на основі тих чи тих історичних фактів, як-от: Коли були ще баба молодими, вони були веселі, як Хуррем [4, с. 387]; Він нам дивився просто в самі душі, $i$, як Батий, очоливши орду, з розбійним свистом разом з нами груші колись обніс у власному саду [4, с. 393]. У першому разі образне порівняння стосується легендарної постаті Роксолани, доньки священика, яка потрапила в султанський гарем. Згідно 3 історичними відомостями, українка вразила работоргівців Бедестана тим, що не плакала, не проклинала, а сміялася. Звідси, відповідно, і поява ймення Хуррем - та, що сміється, яке й лягло в основу порівняння. В іншому контексті репрезентовано образ загальновідомого монгольського хана і полководця, засновника Золотої Орди, який «прославився» своїми розбійницькими нападами на українські землі. У контексті Я виросла у Київській Венеції. Цвіли у нас під вікнами акації. А повінь прибувала по інериії $і$ заливала всі комунікаціï [4, с.70] наявний перифрастичний зворот порівняльного типу. 
Тут відсутні і суб'єкт, і ознака порівняння, які легко реконструюються завдяки позамовним чинникам: з Венецією порівнюється житловий масив Русанівка, розташований на лівому березі Дніпра навпроти Гідропарку. Забудова цього масиву, розпочата в 1961 році, сприяла прокладенню проточного обвідного каналу, який разом з фонтанами утворив своєрідну панораму, завдяки чому Русанівку стали називати Київською Венецією.

Поетичний доробок Ліни Костенко переконливо засвідчує те, що межі міфологічних образів розширюються за рахунок осмислення й переосмислення античних міфів. У такий спосіб вимальовуються образи сирени, Прометея, Деметри, Сізіфа, Одіссея, Януса, як-от, наприклад, у контекстах: Дуже дивний пейзаж: косяками ідуть таланти. Сьоме небо своє пригинав собі суєта. При майстрах якось легше. Вони - як Атланти. Держать небо на плечах. Тому і є висота [4, с. 107]; Мати. Каріатида 3 божсої глини. Підпирає перетрухлі балки своєї хати. Стріха осіла їй на стомлені плечі, солома стирчить між зашкарублими пальцям і ластівка звила гніздо на грудях. Батько. Старий Атлант. 3 могутнього кореня. Шліфований і покорчений тяжккою прачею. Мати тримає на собі хату, батько тримае на собі світ. Отак би я створила їх обох. Сумні у нас селянські пантеони. Бо першим скульптором був Бог. А ми вже тільки епігони [4, с. 153]; Від магістралі за два метри, уся закутана в що $\epsilon$, сидить бабуся, як Деметра, у відрах моркву продає [4, с. 123]; А десь іржаві бомби рибальські рвали сіті. А десь народ іспанський конав, як Прометей [4, с. 121]; Хмари над лісом пливуть перисті. Флегматики вдумливо грають в покер. Підтоптані пари, хакі непаристі, як Януси, дивляться в різні боки [4, с. 399]. Причому в одному контексті можуть реалізуватися як пряме, так і переносне значення. Наприклад, за міфом, Атлант - античний герой, який брав участь у боротьбі титанів проти Зевса, за що був покараний: мусив вічно підпирати небозвід. У переносному використанні звуковий комплекс Атлант означає «велетень» (пор.: майстри, як Атланти, з одного боку, «ті, що держать небо на плечах», 3 іншого, - велетні). У наступному контексті маніфестовано аналогічне образне порівняння, яке увиразнюється тим, що, по-перше, суб'єкти порівняння вступають в антонімічні парадигматичні відношення (батько мати), по-друге, на пряме значення ознаки порівняння накладається переносне: батько, як Атлант, тримає на собі світ; мати, як Каріатида, тримає на собі хату (пор.: Коріатида - статуя одягненої жінки, використовувана в давньогрецькому зодчестві для підтримки антаблемента, заміняла собою колону чи пілястру). У третій ситуації бабуся порівнюється з Деметрою - богинею родючості, хліборобства та шлюбу. Правильне сприйняття запропонованої інфомації залежить від знання всіх деталей, пов'язаних із буттям цього міфологічного персонажа: на зображеннях Деметра сидить на троні з вінком колосків на голові, iз серпом, смолоскипом або кошиком фруктів у руках (звідси, відповідно, 
бабуся сидить, як Деметра). Це, власне, стосується й контексту А затишок співає, мов сирена. Не треба воску, я не Одіссей. Вже леви ждуть, іжде мене арена [4, с. 206], де маніфестовано образи сирени та Одіссея. Перші згадки про сирен засвідчені в «Одіссеї», де розповідається нібито вони живуть на острові й зваблюють усіх мореплавців. Подорожні, почувши їхній спів, забували про все на світі, не могли вже керувати кораблем, підпливали до чарівного острова й гинули. Одіссей, пропливаючи повз той острів, заліпив вуха своїм супутникам воском, а себе наказав прив'язати до щогли. Так він став першою людиною, яка почула спів сирен і залишилася живою (пор.: Світла мрія про Вас співає мені, як сирена. Прив'ялсуся до щзоли $i$ вуха воском заллю. Розумію, ие щастя. Але щастя - воно не для мене. Я боюся Вас, Сво. Я вперше в житті люблю [4, с. 251]).

Подекуди образні порівняння виходять за межі міфології й історії українського народу та вербалізуються запозиченнями, які ілюструють буття, зокрема й міфологічні уявлення, інших народів: Обступи мене, ліс, як в легенді про князя Хетага, коли й кінь був убитий, $і$ він уже ледве брів. Обступи мене, ліс! Хай зупиниться вся ия ватага, хай удариться люттю об спокій твоїх стовбурів [4, с. 183]; Ти пам'ятаєщ, ти прийтов із пристані. Такі сади були тоді розхристані. I вся в гірляндах, як індійська жриця [4, с. 305]; Кошлатий вітер-голодранець в полях розхристує туман, танџюе юродивий танещь, б'є в бубон сония, як иаман [4, с. 332]; Давно колись була ріка Діяла. I иар персидський на імення Кір. I лотоси біліли, мов піали. I берег грав вогнями, як факір [4, с. 355]. Без знання особливостей цього буття іноді важко декодувати репрезентовану у відповідному контексті інформацію. Так, скажімо, вислів Обступи мене, ліс, як в легенді про князя Хетага у буквальному витлумаченні означає «захисти мене». Згідно з легендою аланів, князя Хетага хотіли вбити через неприйняття нової віри. Переслідуваний ворогами по дорозі в Осетію, він знайшов порятунок у лісі. Почувши голос: «Хетаг! У ліс! У ліс!», вигукнув: «Хетаг уже не добереться до лісу, але ліс добереться до Хетага». У цей момент ліс піднявся зі схилу гори й перенісся до місця, де був Хетаг, сховавши його в своїй гущавині.

Окрему групу образних порівнянь утворюють ті, що вибудувалися на основі біблійних сюжетів. Крім уже звичних для української літератури образів Юди, Месії, Ноя і т. ін., з'являються образи Голіафа, Даліли, Самсона, Вельзевула тощо: Прорубане вікно - з укропу у Європу. В Свропі вже був млин, двигучий, паровий. I прадід мій ходив, як Ной після потопу, А я собі, мала, була - як херувим [4, с. 68]; Очі у них великі $і$ круглі. Скелі голі, як Голіафи. Я ніколи не звикну. Я не вмію до тебе звикати. [4, с. 312]; Я дуже тяжко Вами відболіла Це все було як марення, як сон. Любов підкралась тихо, як Даліла, а розум спав, довірливий Самсон [4, с. 288]. Останні образи виникають на основі біблійного сюжету про біблійного богатиря Самсона, що мав надзвичайну фізичну силу, яка знаходилася в 
довгому волоссі. Дізнавшись цю таємницю, Даліла зраджує свого коханого, під час сну обстригає в нього волосся. Довірливого Самсона покидає «сила Божа», а прикликані Далілою воїни виколюють йому очі і заковують у кайдани [1, с. 620]. Цілком очевидно, що письменниця не могла обійти увагою й образи, які уособлюють добро і зло. Образ добра - це образ Ісуса. Примітним $\epsilon$ те, що він репрезентований перифрастичним зворотом: $I$ завжди люди гинули за віру. Цей спорт одвічний винайтли не ми. Тут головне - дивитись в очі звіру і просто - залишатися людьми. Воно в мені, святе моє повстання. Дивлюся я в кривавий ваш туман. Свойм катам $і$ в мить свою останню скажу, як той найперший з християн: - Мене спалить у вас немає змоги. Вогонь холодний, він уже погас. I ваші леви лижуть мені ноги. I ваші слуги насміялись з вас [4, с. 206] (пор.: я скажу, як Ісус та я скажу, як той найперший з християн). Образ зла - це образ Вельзевула - володаря демонів, дияволів, названий у Біблії сатаною [1, с.112]: Отак пройду крізь твій великий подив, не зачеплюсь об лагідні слова. Ти Вельзевул. По душу теж приходив. А я не віддала ї̈- й жива [4, с. 288].

Уже неодноразово акцентувалося на тому, що образні порівняння Ліни Костенко зорієнтовані на підготовленого, ерудованого читача. Це стосується й тих ситуацій, коли, здавалося б, прості речі пояснюються значно складнішими, нетиповими. Їхнє сприйняття вимагає енциклопедичних знань. Такі образні порівняння маніфестують здобутки світової культури: Отак, як $\epsilon$. А може бути й гірше. А може бути зовсім, зовсім зле. А поки розум од біди не згірк щее, - не будь рабом і смійся, як Рабле [4, с. 13], де актуалізуються знання про те, що французький письменник відображає гуманістичні ідеали свого часу через гротеск («Гаргантюа і Пантагрюель»). У контексті У нашому саду була розкішна флора, - жоржини й кропива, любисток і ревень. I прадід мій ходив, як привид Ельсінора, $i$ сойка у кущуах пищзала цілий день [4, с. 68] актуалізуються знання про всесвітньо відому п’єсу В. Шекспіра «Гамлет, принц датський» (привид Ельсінора = привид короля + 3 міста Ельсінора - місця дії п'єси). Наступна ситуація - Колись, давно, були якісь гіганти. Тепер зручніші виміри - пігмей. Напівнездари чи напівталанти, в космічний вік - дрімучий Птолемей [4, с. 207] - актуалізує знання про Клавдія Птоломея - давньогрецького ученого, астронома, який розробив математичну теорію руху планет навколо нерухомої Землі, що дозволило передбачати їхнє положення на небі; разом з теорією руху Сонця і Місяця вона являє собою так звану птолемеївську систему світу [2, с. 221]. У контексті B країні гордій $і$ гористій ия скеля сива, як Софокл. Ї̈ показують туристам, туристи дивляться в бінокль [4, с. 258] актуалізуються знання про давньогрецького поета-драматурга, зокрема в основі порівняння лежать вікові особливості: представник античної трагедії прожив близько 90 років, звідси, відповідно, скеля сива, як Софокл. Знання про індійського письменника й громадського діяча Рабіндраната Тагора, який став першим серед неєвропейців, удостоєних Нобелівської премії з літератури [2, с. 440] 
актуалізуються в контексті Ліси та гори мудрі, як Тагори. Ще, кажуть, мудрі камінь і сова. Де чудодійний корінь мандрагори, щзоб переклав ту мудрість на слова? [4, с. 265]. Порівняння, побудовані на історичних персоналіях, подекуди ілюструють і негативні образи: A maм - Дніпро, аж ген до Базавлука, аж за пороги й далі за лиман. Об иілий світ спіткнулася розлука і йде на нас, страшна, як Тамерлан [4, с. 299] (пор.: Тамерлан середньоазіатський завойовник). Іноді така негативна оцінка спричинена не власне образом порівняння, а семантикою того слова, якому відводиться роль ознаки порівняння: Він був кошмарний, як 3 Агати Крісті, блакитним илейфом в спальні заповзав, Він їх будив, він лоскотав їм ніздрі. - Просніться, люди! - так він їм казав, Мікро-Содом, зашторена Гоморра, просніться, люди, чуєте, біда [4, с. 246] (пор.: Aгата Kрісті англійська письменниця, автор детективних романів, у яких розкриваються заплутані таємниці, пов'язані зі злочином; кошмарний - сповнений кошмарів, важких, страшних, гнітючих видінь; жахливий $[3,460])$. Крім того, у контексті може реалізуватися й подвійна актуалізація, як-от, наприклад: Одні були цзарівен не гірш, а другі - як бідні Міньйони. Хто купляв собі Долю за гріш, А хто - $i$ за мільйони [4, с. 34]. 3 одного боку, наявність протиставного сполучника, що поєднує предикативні частини складносурядного речення, забезпечує не лише протиставні семантикосинтаксичні відношення, але й ілюструє антитезу, яка увиразнюється ще й антонімами (одні - другі); з іншого, - тільки глибинний аналіз дає змогу «відшукати» інтегральні та диференційні семантичні ознаки лексем цзарівна і міньйон: царівна - вродлива, забезпечена особа жіночої статі; міньйон - вродлива, незабезпечена особа чоловічої статі (пор.: міньйон вродливий хлопчик або юнак, коханець у французьких королів [3, с. 531]). На жаль, обсяги запропонованої статті не дозволяють охопити все розмаїння авторських образних порівнянь. Поза нашою увагою залишилися семантичні особливості так званих метафоричних порівнянь у контекстах на зразок: Мені нестерпно, душно, передгрозно, Ліловим чадом туманіє без. Гудуть ліси, риплять дубові кросна [4, с. 270], порівняння, тотожні або споріднені чи то за суб'єктом, чи то за ознакою зіставлення: $У$ хаті глухо, як в печері, Вікно під фресками сльоти. I щзо там пустка Торрічеллі проти такої німоти?! [4, с. 290]; Отак брести. А тиша - як в соборі з давно-давно вигубленим ключем. Холоне степ, $i$ закипілі зорі рогатий жук виймає рогачем [4, с. 299]; Що б не було там, будень чи неділя, не вдаючись ні в який монолог, вони ішли в мовчання, як в підпілля, вони буквально замикались в льох [4, с. 387]; Вони мовчали, як у бастіоні, Вони благань не мали на меті, непереможно безборонні в свойй великій німоті [4, с. 387], а також ті стилістичні прийоми, до яких вдається поетеса, уводячи порівняння в ту чи ту мовленнєву ситуацію: Як батьків гостинець, як хліб солодкий від зайця, як радісне диво найпериих дитячих снів, - хитались у відрах лозові свіжі кружальця, иуміли дуби, $i$ 
стременами вітер дзвенів [4, с. 237]; Я ніколи не звикну. Я не вмію до тебе звикати. Це за примхи мої ти так гарно мене покарав. I приходять світанки, щоденних турбот адвокати, $і$ несуть під пахвою тисячі різних справ [4, с. 312]; Печаль моя - ріка без переправи, на тому бочі спогади живуть. Хати древлянські - трохи пароплави, що по зелених пагорбах пливуть [4, с. 412]; Але, не дай Бог, іскорка десь бликне! Дахи тесові, дерево, сушник. Переморгнуться відблисками вікна, $i$ двір о двір черкнеться, мов сірник. Тому - як герб, як знак нагрудний хати, неодривний настінний календар, - портрет відра, драбини чи лопати, щоб кожен знав, з чим бігти на пожар [4, с. 412] тощо. Їхнє осмислення це вже предмет наступної наукової розвідки. Беззаперечним залишається одне: художнє пізнання дійсності стимулює пошук письменником нових мовних засобів в естетичному освоєнні світу.

Реальне буття мови $є$ безмежним процесом вербальної комунікації, що робить мову необхідним атрибутом людського суспільства, яке накопичує й передає від покоління до покоління свої знання та досвід.

Можливість виникнення образу і ступінь його яскравості залежить від характеру значень лексичних одиниць, на основі яких виникає порівняння. Звернені іноді до інтелекту, а частіше орієнтовані на чуттєве сприйняття, образні порівняння загалом є творчим здобутком, наповнені естетичним смислом і наділені потужними експресивно-емоційними потенціями.

\section{Література}

1. Библейская энциклопедия : репринтное издание / Труд и издание архимандрита Никифора. - М. : «ТЕРРА», 1991. - $902 \mathrm{c.}$

2.Большой энциклопедический словарь :

А. М. Прохоров - М. : Советская энциклопедия, 1991. - Т.2 - 768 с.

3. Великий тлумачний словник сучасної української мови / упорядн. та гол. ред. : В. Т. Бусел. - К. - Ірпінь : Перун, 2001. - 1426 с.

4. Костенко Л. В. Вибране / Ліна Василівна Костенко. - К. : Дніпро, 1989.- 559 с.

5. Павлюк Т. П. Порівняльні звороти в сучасному українському поетичному тексті : автореф. дис. на здобуття наук. ступеня канд. філол. наук : спец. 10.02.01 «Українська мова» Тетяна Павлівна Павлюк. Запоріжжя, 2011. - 20 c.

6. Словник іншомовних слів / [Пустовіт Л. О., Скопненко О. І., Сюта Г. М. та ін.]; за ред. Л. О. Пустовіт. - К. : Довіра, 2000. - 1017 с.

7. Українська мова : Енциклопедія / редкол. В. М. Русанівський, О. О. Тараненко (співголови), М. П. Зяблюк та ін. - К. : Укр. енциклопедія ім. М. П. Бажана, 2000. - С. 469. 